\title{
VÝVOJ NOVÉ SPRÁVKOVÉ MALTY S VYUŽITÍM DRUHOTNÝCH SUROVIN
}

\author{
DEVELOPMENT OF A NEW REPAIR MORTAR USING SECONDARY \\ RAW MATERIALS
}

\author{
Petr Figala ${ }^{1}$ \\ ${ }^{1}$ Fakulta stavební VUT v Brně, Brno University of Technology, Veveř́ 331/95, Czech Republic
}

\begin{abstract}
Abstrakt
Tento článek se zabývá výzkumem nové správkové malty na silikátové bázi modifikované vybranými druhotnými surovinami. Cíle práce je vyvinou novou hmotu vyznačující se chemickou odolností vhodnou pro sanaci kanalizačních betonových konstrukcí. Jako stěžejní parametry pro výběr výsledné receptury byla zvolena odolnost vůči agresivnímu roztoku síranů a vůči napadání biogenní kyselinou sírovou. Chemická odolnost byla testována simulací expozičního prostředí v laboratorních podmínkách, a to dle metodiky normy DIN 19573. Ze získaných výsledků vyplývá, že vhodnou modifikací referenční malty je možné zachovat hodnoty fyzikálně-mechanických charakteristik a zároveň dosáhnout zlepšení chemické odolnosti zkušebních těles. Finální receptura bude dále testována v poloprovozních podmínkách "in situ".
\end{abstract}

\section{Klíčová slova}

Správková malta, chemická odolnost, druhotná surovina, biogenní kyselina sírová, sírany

\begin{abstract}
This paper deals with the research of a new repair mortar modified with secondary raw materials. The aim of the work is to develop a material characterized by chemical resistance suitable for the rehabilitation of sewer concrete structures. Resistance to aggressive sulphate solution and to attack by sulfuric acid was chosen as the key parameters for the choose of a final mixture. Chemical resistance was tested by simulating the exposure environment in laboratory conditions, according to the methodology of DIN 19573. The obtained results show that by suitable modification of the reference mortar it is possible to maintain the values of physical-mechanical characteristics and improve the chemical resistance of test samples. The final mixture will be further tested in field conditions.
\end{abstract}

\section{Key words}

Repair mortar, chemical resistance, secondary raw material, biogenic sulphuric acid, sulphates

\section{1 ÚVOD}

Kanalizační sít' představuje charakteristické expoziční prostředí s vysokými požadavky na odolnost použitých stavebních materiálů. Při sanaci kanalizací je cílem obnovit či prodloužit původní životnost celého stavebního díla. Správkové malty určené primárně k reprofilaci poškozeného betonovému povrchu představují stěžejní hmotu při obnově užitných vlastností sanované stavební konstrukce. Požadavkem na takový typ malt je mimo jiné jednoduchá aplikovatelnost, vysoká pevnost, odolnost vůči mechanickému poškození a odolnost vůči chemicky agresivnímu prostředí.

Výsledky prezentované $\mathrm{v}$ rámci této práce se zaměřují na návrh a studium vybraných charakteristik surovinových variant správkové malty na cementové bázi pro sanaci betonových kanalizačních konstrukcí. Tento vývoj je součástí spolupráce Stavební fakulty VUT v Brně a renomovaného výrobce stavebních hmot. Cílem spolupráce je vývoj uceleného chemicky odolného systému pro sanaci chemicky atakovaných kanalizačních stok či šachet. Receptury správkové malty jsou navrženy tak, aby ve výsledném sanačním systému plnily funkci vysokohodnotné sanační malty pro ruční aplikaci na malých plochách či pro opravu složitějších profilů.

Vzhledem k vysokým nákladům sanačních prací musí nová správková hmota vykazovat dostatečnou životnost, ale být také cenově dostupná. Vzhledem k vysoké ceně vstupních surovin u cementových kompozitů, představuje substituce primárních složek vhodnými druhotnými surovinami vhodnou metodu, za předpokladu zachování či 
zlepšení původních charakteristik výsledného kompozitu. Avšak pro návrh takových sanačních hmot musí být vybrány vhodné materiály. Pro výběr vhodných materiálů podle koncentrace $\mathrm{H}_{2} \mathrm{~S} v$ současné době neexistuje v Evropě souhrnná norma, která by poskytovala informace o materiálech vhodných k použití do těchto expozičních podmínek. Existuje však několik národních standard, které se zabývají návrhem hodnot koncentračních úrovní expozičních prostředí k definování expozičních tříd souvisejících s agresivním chemickým prostředím. Př́ikladem je německý standard DIN 19573 [1], v němž jsou navržena expoziční prostředí chemicky agresivních roztoků $\mathrm{Na}_{2} \mathrm{SO}_{4}$ a $\mathrm{H}_{2} \mathrm{SO}_{4}$ o definovaných koncentracích a také požadavky na zkoušené cementové materiály.

Cílem této práce je modifikování stávající komerčně dostupnou správkovou maltu tak, aby splňovala požadavky pro správkové malty dle německého standardu DIN 19753 [1].

\section{POPIS SOUČASNÉHO STAVU}

Životnost betonové konstrukce se vlivem chemické degradace významně zkracuje. Rychlá degradace cementových kompozitů v prostředí kanalizačních stok je způsobena zejména tím, že kvůli chemickému složení a vysokému obsahu vápníku mají omezenou odolnost vůči působení acidickým útokům. Klasické betonové kanalizační prvky nemají významně zvýšenou chemickou odolnost [2]. Nové betonové prvky je vhodné před zabudování do konstrukce ošetřit sekundární ochranou ve formě chemicky odolného nátěru. Při sanaci je vlivem zvýšené vlhkosti aplikace těchto nátěrů komplikovaná.

Problémy s korozí betonových odpadních systémů jsou známy od počátku minulého století [3], [4]. V některých případech je omezena doba použití betonových stok na méně než 10 let [3]. Největší vliv na snižování doby použitelnosti má v kanalizacích vysoká koncentrace $\mathrm{H}_{2} \mathrm{~S}$. Sulfan vzniká rozkladem organických látek ve splaškách anaerobními bakteriemi nacházejícími se v kanalizačním systému. Pokud existuje v tekutině dostatečné

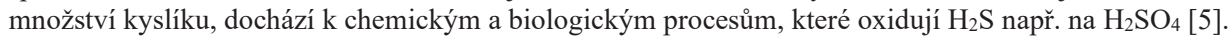

Proces biokoroze betonu je možné popsat třemi kroky: prvním je neutralizace povrchu betonu, čímž vznikne vhodné prostředí pro růst příslušných bakterií oxidujících síru. $\mathrm{K}$ tomu dochází v prostředí s vyšší koncentrací sulfanu. Čerstvý beton může dosahovat hodnot v rozmezí pH 11-13, přičemž kyselé plyny dosahují $\mathrm{pH}<6$. V dalším kroku plynný sulfan na klenbě stok oxiduje. K tomu může dochází nejen biologicky, ale také chemicky. V obou případech se jedná o aerobní proces, kdy jsou k bezkyslíkatému sulfanu $\left(\mathrm{H}_{2} \mathrm{~S}\right)$ připojeny dvě molekuly kyslíku $\left(\mathrm{O}_{2}\right)$ za vzniku kyseliny sírové $\left(\mathrm{H}_{2} \mathrm{SO}_{4}\right)$. V třetím kroku dochází k reakci mezi $\mathrm{H}_{2} \mathrm{SO}_{4}$ a produkty hydratace cementu [5]. Reakce síranů a siřičitanů na povrchu betonu probíhá nejčastěji reakcí portlanditu $\left(\mathrm{CaOH}_{2}\right)$ a dalších minerálů. Jedná o velmi složité fyzikální a chemický procesy [6], jejich součástí jsou mikroskopické procesy difuze síranů a siřičitanů, tvorbu nových produktů s menšími pevnostmi či s expanzním charakterem v pórech a kapilárách a s tím spojený vývin krystalizačního tlaku, a makroskopické procesy - postupné rozpadání cementového kamene [7], [8]. Mezi charakteristické minerály vznikající při tomto typu degradace cementového kamene patří sádrovec $\left(\mathrm{CaSO}_{4} \cdot 2 \mathrm{H}_{2} \mathrm{O}\right)$ a ettringit $\left(3 \mathrm{CaO} \cdot \mathrm{Al}_{2} \mathrm{O}_{3} \cdot 3 \mathrm{CaSO}_{4} \cdot 32 \mathrm{H}_{2} \mathrm{O}\right)$.

Vznik těchto minerálů doprovází výrazné objemové změny, jelikož nově vznikající sloučeniny obsahují velké množství především molekul vody, které $\mathrm{v}$ původních sloučeninách obsaženy nebyly. Například při vzniku sádrovce dochází ke zvětšení objemu na 124 \% původního objemu minerálu a při vzniku ettringitu dokonce na 227 \% původního objemu [8], jiné zdroje uvádění expanzi ettringitu až o 700 \% původního objemu [9].

K urychlení procesu degradace betonu vlivem útoku síranů či siřičitanů dochází při cyklickém vysoušení a namáčení kompozitů [10] a velmi významný vliv má také teplota prostředí [11].

Řada výzkumů je zaměřena na možnosti omezení degradace cementových kompozitů vlivem síranů a siřičitanů částečnou substitucí portlandského cementu vhodnými aditivy či druhotnými surovinami [12], [13]. Bylo zjištěno, že pucolánové př́sady (vysokoteplotní popílek, křemičité úlety, metakaolin, aj.) mají pozitivní vliv na strukturu cementového kamene, distribuci pórů či jejich velikost. Z výsledků jiných studií však vyplývá [14], že i přes tento pozitivní vliv příměsi druhotných surovin může s rostoucí mírou substituce pojiva růst negativní vliv na odolnosti vůči síranové korozi. Cílem je tedy nalézt optimální míru substituce cementového pojiva vhodnými druhotnými surovinami.

\section{METODIKA}

Jak již bylo uvedeno výše, referenční hmotu (SM-R) představuje komerčně dostupná správková matla a návrh jednotlivých nových receptur testovaných v rámci této práce se zakládá na substituci 10-30 \% pojiva (CEM I 42,5 R) vybranými druhotnými surovinami. Vzhledem k tomu, že zmiňovaný výzkum stále probíhá, je v Tab. 1 uvedeno pouze orientační zastoupení jednotlivých surovin v jednotlivých recepturách, přičemž ty se liší pouze použitou druhotnou surovinou. Označení jednotlivých surovinových variant správkové malty SM-A(B,C)10(20,30) je voleno s ohledem na danou druhotnou surovinu -,„A“ vysokoteplotní popílek 
z hnědouhelné elektrárny Tušimice; „B“ kamenné odprašky z kamenolomu Želešice; „C“ mletá silica vyzdívka z hutí Arcelor Mittal. Pro prríklad receptura SM-B20 představuje správkovou maltu s 20\% mírou substituce cementu kamennými odprašky.

Vysokoteplotní popílek splňuje požadavky na popílky pro stavební účely ČSN 72 2071. Silica vyzdívka byla dodána ve formě valounů, které byly nejprve rozmělněny v čelist'ovém drtiči a následně byly surovina upravena mletím na měrný povrch $435 \mathrm{~m}^{2} \cdot \mathrm{kg}^{-1}\left( \pm 50 \mathrm{~m}^{2} \cdot \mathrm{kg}^{-1}\right)$. Tento měrný povrch pro mletí by volen $\mathrm{v}$ souladu s měrným povrchem substituovaného pojiva. Vybrané kamenné odprašky byly dodány ve formě suchého prášku, nebylo je tedy nutné před použitím nijak upravovat.

Tab. 1 Průměrné surovinové složení zkušebních receptur vyvíjené správkové malty.

\begin{tabular}{ccc}
\hline Surovina & Průměrný podíl surovin ve vyvíjené směsi [hm. \%] \\
\hline Cement CEM I $-42,5 \mathrm{R}$ & 20,3 & 30,6 \\
Směr př́sad [hm.\% z m $]$ ] & 0,84 & 1,84 \\
Druhotná surovina & 2,9 & 10,2 \\
Jemně mletý vápenec & 3,0 & 6,0 \\
Křmičitý písek $0,18-1,0$ & 34 & 37,0 \\
Křemičitý písek $0,6-1,0$ & 17,0 & 21,0 \\
Křemičitý písek $1,0-4,0$ & 3,0 & 6,0 \\
\hline
\end{tabular}

\section{Výroba zkušebních těles}

Pro správné spolupůsobení všech složek obsažených ve správkové maltě, byly veškeré vstupní suroviny homogenizovány pomocí kontejnerového homogenizátoru. Pro zajištění dokonalého promísení jednotlivých složek byla minimální doba homogenizace stanovena na 30 minut.

Výroba čerstvé směsi byla prováděna v souladu s normou EN 196-1:2016. Doba míchání byla $270 \pm 5$ sekund. Po zamíchání byla ověřena konzistence čerstvé malty v souladu s normou EN 1015-3. Poměr voda/cement (w) byl zvolen tak, aby konzistence jednotlivých čerstvých malt odpovídala zvolené optimální konzistenci 137,5 \pm $5 \mathrm{~mm}$. Vliv príměsi jednotlivých druhotných surovin na spotřebu záměsové vody byl zanedbatelný a hodnota "w" byla v př́ípadě všech testovaných receptur téměř identická.

Veškeré míchání bylo prováděno $\mathrm{v}$ laboratorní míchačce $\mathrm{s}$ nuceným oběhem při nastavených otáčkách v souladu s normou ČSN EN 196-1 a v laboratorních podmínkách $\left(23 \pm 2{ }^{\circ} \mathrm{C}, 55 \pm 5 \%\right.$ relativní vlhkosti vzduchu). Nastavení míchačky bylo zvoleno pro dokonalé promísení suché směsi se záměsovou vodou a zaktivování práškových příměsí intenzivním mícháním.

Všechna zkušební tělesa byla po dobu prvních 24 hodin od zamísená ponechána ve formách v prostředí s teplotou $20 \pm 1{ }^{\circ} \mathrm{C}$ a relativní vlhkostí vzduchu $90 \%$. Po odformování byla zkušební tělesa uložena do vodní lázně, kde byla ponechána až do doby provedení př́slušné laboratorní zkoušky.

\section{Zkušební metody}

Fyzikálně-mechanické charakteristiky. Konzistence čerstvých mat byla ověřena pomocí střásacího stolku, v souladu s normou ČSN EN 1015-3. Pevnost v tlaku zkušebních těles $(40 \times 40 \times 160 \mathrm{~mm})$ byla stanoveny v souladu s ČSN EN 12190:1998 po 28 dnech zrání. U vzniklých fragmentů zkušebních těles byla stanovena nasákavost cementového kompozitu, a to v souladu s ČSN 722448.

Stanovení síranové odolnosti. Zkušební tělesa $(10 \times 40 \times 160 \mathrm{~mm})$ byla po dobu 90 dní vystavena působení agresivního roztoku síranů o koncentraci 29,8 g/l (44 g/1 Na $\mathrm{SO}_{4}$ ) Zkušební tělesa byla po odformování uložena do vodní lázně a samotné chemické zatěžování bylo započato po $60 \pm 3$ dnech od jejich výroby. Před započetím chemického zatěžování bylo potřeba na všechna tělesa upevnit měřící terče. V průběhu zrání tedy byla tělesa vyjmuta z vodního uložení, vysušena, na jejich povrch byly upevněny měříí terče, a po vytvrzení byla tělesa vrácena do vodního uložení. Před začátkem chemického zatěžování musela být tělesa soustavně ve vodním uložení alespoň 14 dní. Z důvodu zohlednění průhybu zkušebních těles byly terče upevněny na obě strany daných těles. Č́st těles byla po celou dobu ponechána ve vodním uložení - referenční tělesa, $2 / 3$ těles byly uloženy do výše zmíněného síranového roztoku, který byl pravidelně obměňován. Měření změny délky probíhalo v sedmidenních intervalech. Příprava těchto zkušebních těles i samotné měření bylo v souladu s ČSN EN 12617-4.

Norma DIN 19573 definuje hraniční hodnotu změny délky $(\Delta \varepsilon<0,8 \mathrm{~mm} / \mathrm{m})$, jež se stanoví porovnáním průměrných délkových změn zkušebních těles vystavených síranům a referenčních zkušebních těles.

Stanovení odolností vůči biogenní kyselině sírové. Pro stanovení odolnosti byl použit roztok kyseliny sírové o koncentraci $\mathrm{c}\left(\mathrm{H}_{2} \mathrm{SO}_{4}\right)=1,0 \mathrm{~mol} / 1(\mathrm{pH}=0)$. Zkušební tělesa $(40 \times 40 \times 80 \mathrm{~mm})$ byla vystavena působení daného roztoku po dobu 14 dní. Po odformování zkušebních těles byly z jejich povrchu odstraněny všechny nesoudržné 
částice včetně svrchní vrstvy cementového tmele, případně zbytky odbedňovacího přípravku. Takže připravená tělesa byla, do $60 \pm 3$ dní od jejich výroby, uložena do vodní lázně. Třetina sady zkušebních těles byla ponechána ve vodním uložení po celou dobu trvání zkoušky. Zbývající tělesa byla po uplynutí doby zrání změřena, zvážena a byla umístěna do kádě s roztokem kyseliny sírové. Koncentrace roztoku byla pravidelně kontrolována a denně srovnávána titrací koncentrované $\mathrm{H}_{2} \mathrm{SO}_{4}$. Po ukončení zkoušky byl ze všech zkušebních těles odstraněn nesoudržný materiál, byly zaznamenány rozměry, hmotnost a byla pořízena fotodokumentace. Z takto předpřipravených těles byly vyhotoveny kvádry o $\mathrm{h}=40 \pm 1 \mathrm{~mm}$. Stejným způsobem byly vyrobeny krychle (o hraně a $=40 \pm 1 \mathrm{~mm}$ ) i z referenčních těles ponechaných ve vodním uložení.

U všech těchto těles byla stanovena pevnost v tlaku dle ČSN EN 196-1:2016. Ze získaných výsledků byl matematicky vyjádřena relativní zbytková pevnost $\mathrm{v}$ tlaku $\mathrm{f}_{\text {crr }}$ a celková hloubka koroze $\mathrm{X}_{\mathrm{f}, \mathrm{D}}$, která se taktéž vztahuje k pevnosti v tlaku, avšak zohledňuje také úbytek objemu vlivem koroze cementového kamene.

\section{VÝSLEDKY}

Na Obr. 1 jsou graficky vyjádřeny výsledky stanovení nasákavosti a pevnosti v tlaku zkušebních těles jednotlivých surovinových variant správkové malty po 28 dnech zrání ve vodním uložení.

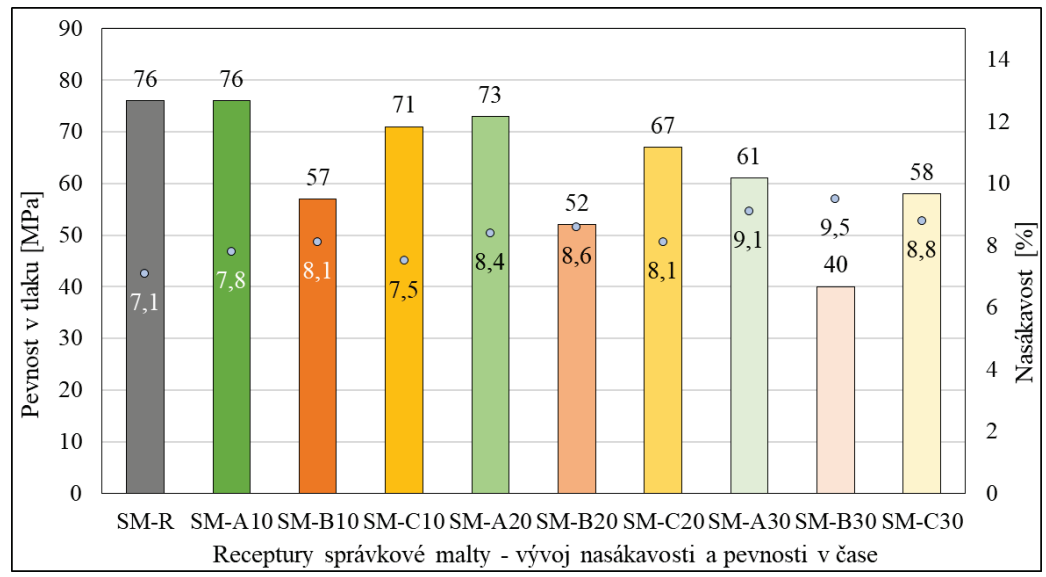

Obr. 1 Výsledky vybraných fyzikálně-mechanických charakteristik jednotlivých surovinových variant.

Na Obr. 2 je graficky vyjádřen průběh délkových změn zkušebních těles vybraných surovinových variant způsobený síranovou korozí.

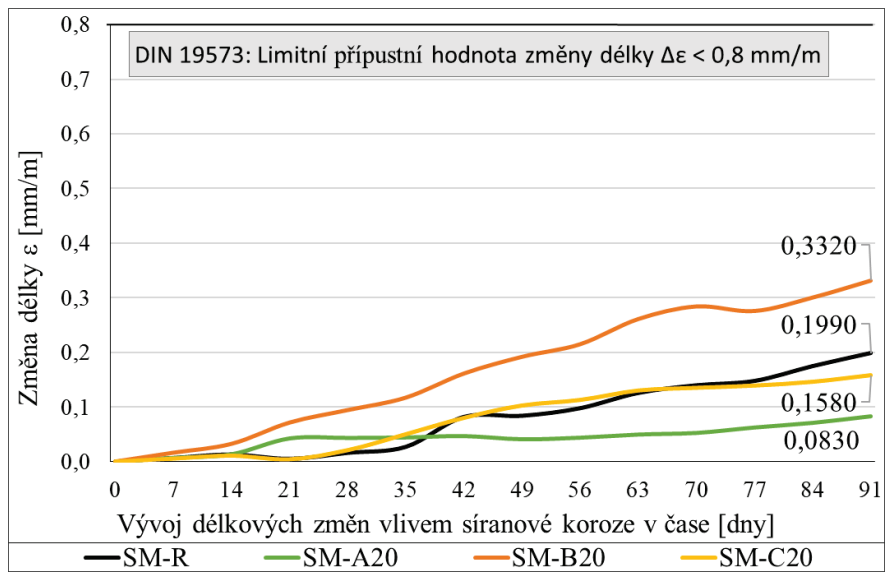

Obr. 2 Průběh objemových změn zkušebních těles vlivem působení síranové koroze v čase. 
V Tab. 2 jsou uvedeny všechny zbývající výsledky, zkušebních těles vybraných surovinových variant, chemické odolnosti dle DIN 19573. Uvedena je průměrná konečná délková změna, po 91 dnech zatěžování síranovou korozí, porovnaná s objemovými změnami referenčních těles, jež byly po celou dobu uloženy ve vodním uložení. Dále jsou uvedeny výsledky odolnosti, zkušebních těles týž surovinových variant správkové malty, vůči působení roztoku agresivní kyseliny sírové o koncentraci $\mathrm{c}\left(\mathrm{H}_{2} \mathrm{SO}_{4}\right)=1,0 \mathrm{~mol} / 1$ po dobu 14 dní. Konkrétně jsou uvedeny výsledky stanovení hloubky koroze zkušebních těles $\left(\mathrm{X}_{\mathrm{f}, \mathrm{D}}\right)$ a relativní zbytkové pevnosti v tlaku $\left(\mathrm{F}_{\mathrm{crr}}\right)$.

Tab. 2 Výsledky stanovení chemické odolnosti zkušebních těles vybraných surovinových variant dle DIN 19573.

\begin{tabular}{cccc}
\hline Receptura & $\Delta \boldsymbol{\varepsilon}[\mathbf{m m} / \mathbf{m}]$ & $\mathbf{X}_{\mathbf{f}, \mathbf{D}}[\mathbf{m m}]$ & $\mathbf{F}_{\text {crr }}[\mathbf{\%}]$ \\
\hline SM-R & 0,1790 & 1,707 & 80,5 \\
SM-A20 & 0,0580 & 2,202 & 73,6 \\
SM-B20 & 0,2320 & 1,238 & 84,9 \\
SM-C20 & 0,1080 & 1,686 & 81,4 \\
\hline
\end{tabular}

\section{DISKUZE}

Na základě výsledků vybraných fyzikálně-mechanických charakteristik (Obr. 1.) byl původní poměrně široký soubor surovinových variant zúžen. Z uvedených výsledků pevnosti v tlaku vyplývá, že náhradou cementu v míře 20 i 30 \% je možné dosáhnout vyhovujících charakteristik. Naopak, vyšší míra substituce pojiva se jeví jako přehnaná. Z výsledků nasákavosti zkušebních těles je však zřejmé, že již 30\% míra substituce má poměrně významný negativní vliv na daný parametr.

Soubor receptur pro stanovení chemické odolnosti dle DIN 19573 byl zúžen pouze na receptury s 20\% mírou náhrady pojiva jednotlivými druhotnými surovinami.

Na Obr. 2. a v Tab. 2 jsou uvedeny výsledky chemické odolnosti zkušebních těles vybraných receptur správkové malty. Z uvedených výsledků vyplývá, že substitucí $20 \%$ pojiva je možné při volbě správné druhotné suroviny dosáhnout zlepšení odolnosti výsledného cementového kompozitu. V rámci síranové odolnosti byl splněn požadavek na limitní př́ípustnou délkovou změnu po ukončení zatěžování $\Delta \varepsilon<0,8 \mathrm{~mm} / \mathrm{m}$. Konkrétně bylo nejlepších výsledků dosaženo u receptury s $20 \%$ náhradou cementu vysokoteplotním popílkem. Je zřejmé, že pucolánový charakter této druhotné suroviny měl pozitivní vliv na potlačení objemových změn zkušebních těles. Konkrétně došlo, ve srovnání s referenční hmotou, k potlačení délkových změn o více než $65 \%$. Pouze v případě receptury s 20\% mírou substituce pojiva kamennými odprašky došlo, ve srovnání s referenční hmotou, k zhoršení sledovaného parametru.

V př́ípadě této receptury bylo naopak dosaženo nejlepších výsledků při stanovení odolnosti vůči působení roztoku agresivní kyseliny sírové. Zlepšení v charakteristice relativní zbytkové pevnosti v tlaku bylo dosaženo i v prípadě surovinové varianty s $20 \%$ mírou substituce cementu mletou silica vyzdívkou. Naopak, zhoršení odolnosti ve srovnání s referenční hmotou bylo zaznamenáno z receptury s vysokoteplotním popílkem. Důvody těchto trendů je třeba dále hlouběji studovat.

\section{ZÁV̌̌R}

Cílem této práce bylo ověřit možnost zvýšení či alespoň zachování chemické odolnosti a také fyzikálněmechanických parametrů správkové malty, při jejíž návrhu byla určitá část pojiva substituována vybranou druhotnou surovinou. Z výsledků uvedených v této práci vyplývá, že hlavní cíl byl slněn.

Předpoklad, že při vhodné míře substituce cementu správnou druhotnou surovinou dojde ke zlepšení chemické odolnosti, se bezezbytku potvrdil. Zároveň se potvrdil předpoklad, že po 28 dnech zrání dojde k mírnému zhoršení sledovaných fyzikálně-mechanických charakteristik.

Jako optimální pro další výzkum se jeví dvě druhotné suroviny - vysokoteplotní popílek a mletá silica vyzdívka. V př́padě receptury SM-C20, s 20\% mírou substituce cementu silica vyzdívkou, bylo dosaženo velmi dobrých výsledků ve všech sledovaných parametrech, ve většině případů se však nejednalo o nejlepší výsledky. Až na nasákavost a odolnost vůči biogenní kyselině sírové se jako optimální jevila př́měs vysokoteplotního popílku. V př́ípadě síranové odolnosti i pevnosti v tlaku byly výsledky surovinové varianty SM-A20, s 20\% mírou substituce cementu vysokoteplotní popílkem, dosaženo skvělých výsledků.

Na základě získaných výsledků, jako relativně nízká odolnost hmoty s popílkem vůči působení roztoku kyseliny sírové, bude probíhat hlubší studium vlivu vybraných druhotných surovin na stanovené výsledky. 


\section{Poděkování}

Článek byl vytvořen $\mathrm{z}$ finančních prostředků státního rozpočtu prostřednictvím Ministerstva průmyslu a obchodu ČR v rámci projektu FV20149 „Ucelený systém pro sanaci chemicky atakovaných a namáhaných stavebních konstrukcí“ a v rámci projektu FAST-J-21-7312 "Studium vlastností chemicky odolné správkové hmoty na silikátové bázi s využitím druhotných surovin".

\section{Použité zdroje}

[1] DIN 19753, Draft on mortars for construction and rehabilitation sewer system. La Plaine Saint-Denis Cedex, 2017.

[2] Park JS. Necessity of rehabilitation and current state of domestic sewage pipe network. J Korean Soc Civ Eng 2007;55:135-43.

[3] PARKER, C. D. Species of sulphur bacteria Associated with the Corrosion of Concrete. Nature. 1947, (159 (4039), 439-440. ISSN 1476-4687.

[4] GRANDCLERC, Anaïs, Marielle GUÉGUEN-MINERBE, Issam NOUR, Patrick DANGLA a Thierry CHAUSSADENT. Impact of cement composition on the adsorption of hydrogen sulphide and its subsequent oxidation onto cementitious material surfaces. Construction and Building Materials. 2017, 152, 576-586. ISSN 09500618.

[5] YUAN, Haifeng, Patrick DANGLA, Patrice CHATELLIER a Thierry CHAUSSADENT. Degradation modeling of concrete submitted to biogenic acid attack. Cement and Concrete Research. 2015, 70, 29 38. ISSN 00088846.

[6] MONTEIRO, Paulo J.M. a Kimberly E. KURTIS. Time to failure for concrete exposed to severe sulfate attack. Cement and Concrete Research. 2003, 33(7), 987-993. ISSN 00088846.

[7] YIN, Guang-Ji, Xiao-Bao ZUO, Xiang-Nan LI a Yu-Xiao ZOU. An integrated macro-microscopic model for concrete deterioration under external sulfate attack. Engineering Fracture Mechanics. 2020, 240. ISSN 00137944.

[8] J. Ledererová, et al., Biocorrosive effects on building structures, (Biokorozní vlivy na stavební díla), first ed., Prague: Silikátový svaz, 2009.

[9] CHANG, Han Byeol a Young Cheol CHOI. Accelerated performance evaluation of repair mortars for concrete sewer pipes subjected to sulfuric acid attack. Journal of Materials Research and Technology. 2020, 9(6), 13635-13645. ISSN 22387854.

[10] XIE, Feng, Jingpei LI, Gaowen ZHAO, Pan ZHOU a Hongjiang ZHENG. Experimental study on performance of cast-in-situ recycled aggregate concrete under different sulfate attack exposures. Construction and Building Materials. 2020, 253. ISSN 09500618.

[11] HOSSACK, Ashlee M. a Michael D.A. THOMAS. The effect of temperature on the rate of sulfate attack of Portland cement blended mortars in Na2SO4 solution. Cement and Concrete Research. 2015, 73, 136-142. ISSN 00088846.

[12] AL-AKHRAS, Nabil M. Durability of metakaolin concrete to sulfate attack. Cement and Concrete Research. 2006, 36(9), 1727-1734. ISSN 00088846.

[13] HOU, Pengkun, Zhaoheng GUO, Qinfei LI, et al. Comparison study on the sulfate attack resistivity of cement-based materials modified with nanoSiO2 and normal SCMs: Pore structure and phase composition. Construction and Building Materials. 2019, 228. ISSN 09500618.

[14] LIU, Zanqun, Wenlong HU, Le HOU a Dehua DENG. Effect of carbonation on physical sulfate attack on concrete by Na2SO4. Construction and Building Materials. 2018, 193, 211-220. ISSN 09500618. 